\title{
MECHANISM OF THE CARCINOGENIC ACTION OF BENZENE: IRREVERSIBLE BINDING TO RAT LIVER DNA
}

\author{
W.K. LUTZ and CH. SCHLATTER \\ Institute of Toxicology, Federal Institute of Technology and University of Zurich, \\ CH-8603 Schwerzenbach (Switzerland)
}

(Received May 12th, 1977)

(Accepted June 6th, 1977)

\section{Introduction}

It has been established that exposure of animals and men to benzene (see Ref. 1 for a recent review on benzene toxicity) can result in damage to the naematopoietic system and a relationship between such exposure and the development of leukemia is suggested by many case reports [2]. Since a common feature of chemical carcinogens is their interaction with biological macromolecules [3], most probably a covalent binding of a reactive metabolite to DNA, and since the carcinogenicity of benzene to animals has not yet been unequivocally proved, we thought it necessary to examine the interaction of benzene with DNA.

We have exposed adult male rats to radioactive benzene (tritium or carbon-14 label) in a closed inhalation chamber and were able to show for the first time a covalent binding of a benzene metabolite to DNA in vivo. The liver was chosen as a model system since it is the main organ for the metabolism of foreign compounds containing all the enzymes necessary for an activation and since this organ provides ample DNA for the determination of low specific radioactivity.

\section{Materials and methods}

Labeled benzene was obtained from ICN at a specific activity of $1.8 \mathrm{Ci}$ / mmole (tritium) or $35.8 \mathrm{mCi} / \mathrm{mmole}$ (carbon-14) and was diluted, if necessary, to the total dose indicated on line 2 of the table. The total amount of radioactivity used for one animal is given on line 3.

Adult male rats (SIV 50, 270-340 g) were exposed for the period of time indicated on line 4.

The closed inhalation system, which will be described in detail elsewhere [4], consisted of a 2-1 desiccator. The expired carbon dioxide was adsorbed with soda lime at the bottom of the desiccator and the resulting reduced pressure was balanced with oxygen. The radioactive benzene was transferred 


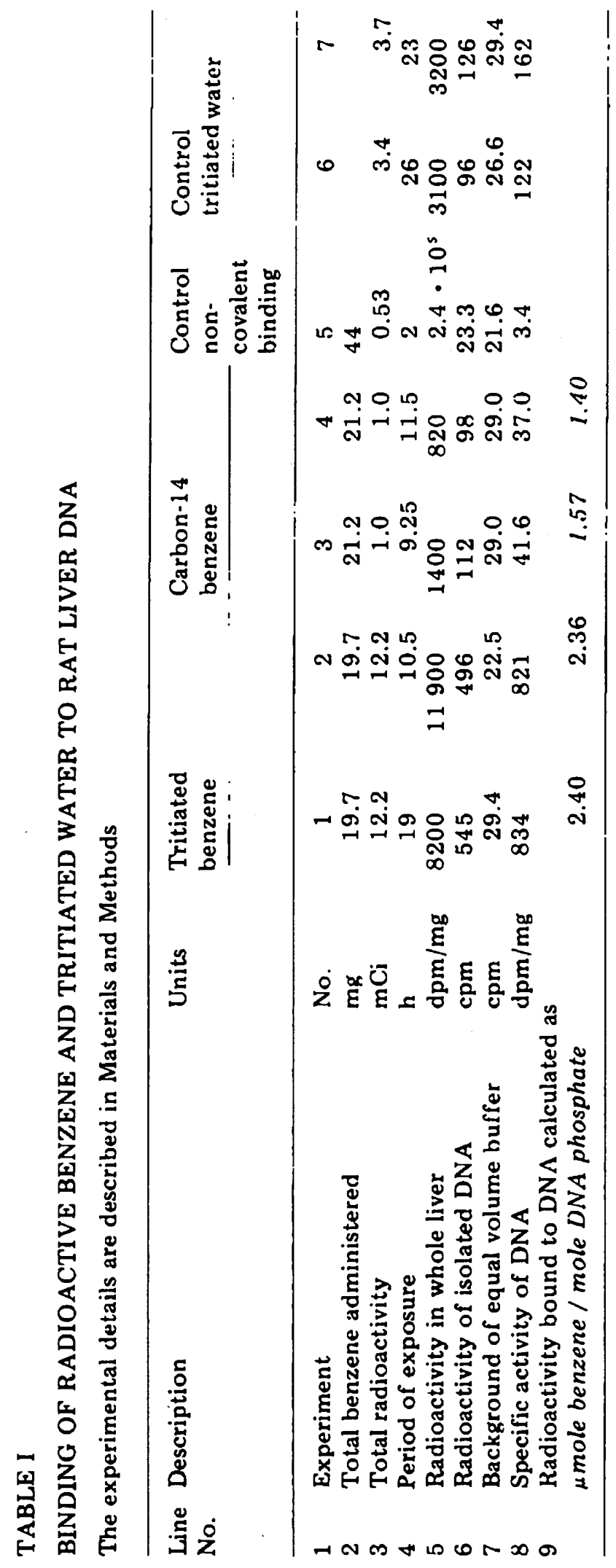


into the chamber in the oxygen supply stream. The exposure was stopped when the benzene concentration in the chamber had fallen below $0.1 \mathrm{mg} / \mathrm{l}$.

The liver was excised under ether anaesthesia, frozen over liquid nitrogen and stored at $-20^{\circ} \mathrm{C}$ until further use. DNA was isolated from the big liver lobe (3-4 g) according to Markov and Ivanov [5], by a method yielding a DNA $(2.1-2.6 \mathrm{mg})$ with maximal contaminations of $1 \%$ RNA and $0.1 \%$ protein.

The radioactivity of whole liver (line 5 of the table) was determined after digestion of about $50 \mathrm{mg}$ wet tissue in Soluene 100 (Packard). Purified DNA was dissolved in 3-4 ml $0.014 \mathrm{M}$ sodium phosphate buffer, $\mathrm{pH}$ 6.8. The radioactivity was counted in $10 \mathrm{ml}$ Insta-Gel (Packard).

The binding of benzene to DNA is expressed on a molar ratio on line 9 .

\section{Results}

The first two experiments (column 1 and 2) were performed with tritiated benzene and revealed a considerable amount of radioactivity on the DNA (line 6). Since part of the tritium label is lost from benzene during its oxidation and could be incorporated into DNA during its biosynthesis the apparent binding of tritiated benzene to DNA (line 9) must be interpreted with caution.

Therefore, carbon-14 labeled benzene had to be used. The results of these experiments are given in column 3 and 4 of the table clearly showing that about $1.5 \mu$ mole benzene is bound per mole DNA phosphate. To prove a covalent binding, the following control experiment was performed (column $5)$ : $44 \mathrm{mg}$ tritiated benzene $(0.52 \mathrm{mCi})$ were added to the homogenate of an inactive big liver lobe in $25 \mathrm{ml}$ lysing medium. The minute amount of radioactivity found on the DNA after this incubation shows that non-covalently bound benzene is removed from DNA during the isolation procedure.

As has been pointed out above, the apparent difference of about $60 \%$ in the binding of tritium or carbon-14 label to DNA could be attributed to the incorporation of tritium from water into DNA, which should account for about $300 \mathrm{dpm} / \mathrm{mg}$ DNA of the specific activity in experiments 1 and 2 (line 8). The control experiments 6 and 7 show that the incorporation of tritium from an external dose of tritiated water is about $40 \mathrm{dpm} / \mathrm{mg}$ DNA per $\mathrm{mCi}$ gavaged water after one day. One would therefore expect the release of more than $8 \mathrm{mCi}$ tritiated water from benzene for an explanation of the difference of $300 \mathrm{dpm} / \mathrm{mg}$ DNA. This is much more than is actually formed since only a very small percentage of the radioactivity in the urine collected from Exp. 2 was found to be tritiated water. The discrepancy is most probably due to the fact that with tritiated benzene the release of tritium occurs at the site of metabolism only. The intracellular specific activity and the corresponding incorporation into DNA will therefore be higher than from the external dose in our control experiments which is diluted into the total water pool of the animal. 


\section{Discussion}

Our experiments have revealed a covalent interaction of a benzene metabolite with DNA in vivo, but do not give any information about the chemical nature of this metabolite. A likely intermediate in benzene metabolism [1] is benzene oxide. In neutral aqueous media it rearranges only slowly to the phenol [6] so that its lifetime could be long enough for a diffusion from the site of activation to the DNA. Alternatively, the metabolic appearance of polyhydroxy derivatives suggests the formation of a phenol epoxide, so that the reactive molecule could be a secondary metabolite like in the case of benzo(a)pyrene where a diolepoxide has been found as the ultimate carcinogen [7]. Only a chemical analysis of the nucleosides will answer this question.

'To get a better idea of the alkylating and perhaps carcinogenic potency of benzene, we can compare it to the typical alkylating and hepatocarcinogenic agent $N, N$-dimethylnitrosamine (DMN): Chronic feeding of adult rats with $50 \mathrm{ppm}$ DMN, which is equivalent to about $4 \mathrm{mg} / \mathrm{kg}$ per day leads to liver tumours in almost $100 \%$ of the animals [8]. The reaction of a single intraperitoneal dose of $2 \mathrm{mg} / \mathrm{kg}$ produces in the liver $0.5 \mu$ mole methylations per g DNA [9], which is about $150 \mu$ mole methylations per mole DNA phosphate. Our benzene dose of $60 \mathrm{mg} / \mathrm{kg}$ is 30 times higher but yields only $1.5 \mu$ mole alkylated nucleotides per mole DNA phosphate. The alkylating potency of benzene to liver DNA is therefore about 3000 times lower than that of DMN.

This comparison shows how potent an alkylation assay can be for the screening of weak carcinogens. With a radioactive material of high specific activity we can detect a reaction with DNA at a level which is ineffective in a long-term carcinogenicity study.

In the complete process leading to a chemically induced cancer many more parameters play an important role, such as the repair capacity of the cell or the mutagenicity of that specific type of damage. A positive answer in an alkylation assay will therefore only be a warning sign but a strong reason for further studies.

1 R. Snyder and J.J. Kocsis, Current concepts of chronic benzene toxicity, CRC Crit. Rev. Toxicol., 3 (1975) 265.

2 IARC Monographs on the Evaluation of Carcinogenic Risk of Chemicals to Man, International Agency for Research on Cancer, Lyon, 7 (1974) 203.

3 J.A. Miller, Carcinogenesis by chemicals: an overview, G.H.A. Clowes Memorial Lecture, Cancer Res., 30 (1970) 559.

4 W.K. Lutz and Ch. Schlatter, Toxicol. Lett. (1977) in press.

5 G.G. Markov and I.G. Ivanov, Hydroxyapatite column chromatography in procedures for isolation of purified DNA, Analyt. Biochem., 59 (1974) 555.

6 E. Vogel, W.A. Böll and H. Günther, Oxepin-Benzoloxyd-Valenztautomerie, Tetrahedron Lett. $1965,609$.

7 P. Sims, P.L. Grover, A. Swaisland, K. Pal and A. Hewer, Metabolic activation of benzo(a)pyrene proceeds by a diol-epoxide, Nature (Lond.), 252 (1974) 326. 
8 P.N. Magee and J.M. Barnes, The production of malignant primary hepatic tumours in the rat by feeding dimethylnitrosamine, $\mathrm{Br}$. J. Cancer, 10 (1956) 114.

9 P.J. O'Connor, M.J. Capps and A.W. Craig, Comparative studies of the hepatocarcinogen $N, N$-dimethylnitrosamine in vivo: Reaction sites in rat liver DNA and the significance of their relative stabilities, Br. J. Cancer, 27 (1973) 153. 